\author{
돼지 MC1R 유전자변이의 양돈산업 적용 \\ 하유경*·최정석*·김상욱*·최양일*·이승수**·최재원***·전순홍*** · 김관석* \\ 충북대학교 농업생명환경대학 축산학과* 국립축산과학원 개량평과과**, 충청북도 축산위생연구소***
}

\title{
Commercial Application of Porcine MC1R Gene Polymorphisms to Korean Pork Industry
}

\author{
You-Kyoung Ha*, Jung-Suk Choi*, Sang-Wook Kim*, Yang-Il Choi*, Seug-Soo Lee**, Jae-Won Choi***, \\ Soon-Hong Jeon*** and Kwan-Suk Kim* \\ Department of Animal Science, Chungbuk National University*, National Livestock Research Institute**, \\ ChungBuk Institute of Livestock and Veterinary Research***
}

\begin{abstract}
The pork from black-coated pigs is famous among-consumers for better eating quality. The loci affecting black coat color was identified in pig chromosome 6 in which several genetic effects on pork quality have been reported. The melanocortin 1 receptor (MC1R) gene is a major gene which plays a key role in regulation of eumelanin (black/brown) and phaeomelanin (red/yellow). In this study, the MC1R gene polymorphism was analyzed for pig breed determination and genetic association with pork quality traits. MC1R Ala243Thr variation was analyzed to determine a specific genotype for four commercial pig breeds (Landrace, Yorkshire, Berkshire and, Duroc) and a Korean native pigs (KNP). Then we developed original KNP-specific DNA markers to determine the pork from black-coated pigs using MC1R DNA sequences. The total length of the MC1R coding sequence ranged $1451 \mathrm{bp}$ in KNP. KNP had the 0201 allele pertaining to $E^{D I}$ but some of the KNP had the $E^{P}$ allele, probably reflecting the geneticintrogression of $E^{P}$ allele into KNP. Furthermore, a relationship between Leu102Pro single nucleotide polymorphism (SNP) genotype and pork quality phenotype were analyzed in F2 reciprocal-crossbred population between KNP and Yorkshire. Association analysis indicated that the allele of the MC1R gene has no effect on pork quality. These results suggest that black coat-color is not directly associated with preferred pork quality, but the black-coat color pig breed may have other genetic components for superior pork quality.
\end{abstract}

(Key words: MC1R, KNP, Polymorphism, Pork quality)

\section{I. 서 론}

가축의 모색은 개체의 외형적 특성을 나타내는 대표적 인 유전형질로 품종을 구분하는 일차적인 수단이 된다. 그러나 표현형으로 구분되는 품종이어도 도축하여 고기의 형태로 전환이 되면 생산된 고기의 기원에 대한 정확한 식별이 어려워지게 된다. 최근 대부분의 돼지고기가 생산 자와 유통업체, 그리고 사료회사 및 지방자치단체 등에서 각자의 브랜드를 걸고 거래되고 있는데, 차별화된 품질의 돼지고기를 생산하고 우수한 육질의 종돈을 품종교배에 이용하는 고급 브랜드제품으로서의 이미지를 높이는데 흑 모색을 가진 돼지고기 (흑돈)를 마케팅에 이용하고 있다.

돼지의 모색은 돼지6번 염색체 단완의 Extension 좌위에 서 발현되는 melanocortin-1 receptor(MC1R) 유전자가 멜라
닌 합성과 확산 현상을 조절함으로써 결정된다 (Mariani 등, 1996). 그 동안 $\mathrm{MC1R}$ 유전자의 모색 변이에 관한 연 구가 소 (Klungland et al., 1995), 말 (Marklund 등, 1996), 개 (Newton 등, 2000) 그리고 닭 (Takeuchi 등, 1997)에서 수행 되어 왔으며, 사람에서는 20 여 개 이상의 변이들이 발견 되었는데 일부는 붉은색 머리카락이나 흰 피부색에 관련 하는 요인으로 보고되었다(Valverde 등, 1995). 최근까지 돼지에서의 $\mathrm{MC} 1 \mathrm{R}$ 유전자 변이를 5 가지 대립유전자 $\left(E^{+}\right.$, $\left.E^{D 1}, E^{P}, E^{D 2} \cdot e\right)$ 로 분류하였는데 각각의 대립유전자가 조 합하여 $1 / 1,2 / 2,3 / 3,3 / 4,4 / 4$ 의 유전자형을 만들어낸다. 이 러한 돼지 MC1R 대립유전자를 이용하여 Kijas 등 (1998) 은 돼지 품종 별 $\mathrm{MC1R}$ 유전자형을 분석하였는데 그 결과 유럽 야생돼지는 $M C 1 R^{*} 1$ 에 상응하는 $E^{+}$형으로 고정되어 있고 유럽 야생돼지에서만 유일하게 나타났으며, 흑모색

Corresponding author : Dr. Kwan-Suk Kim, Department of Animal Science, Chungbuk National University, Cheongju, Chungbuk, 361-763 Korea. Tel: 043-261-2547, Fax: 043-273-2240, E-mail: kwanskim@chungbuk.ac.kr 
을 가지고 있는 Large black과 Meishan은 $M C 1 R * 2$ (Val92Met and Leu99Pro)로 $E^{D 1}$ 에 상응하였다. $M C 1 R^{*} 3$ 의 allele는 두 개의 유전자형이 존재 하는데 첫 번째는 검은 바탕에 흰색 띠나 흰색반점이 있는 Hampshire와 Berkshire 가 속하는 $E^{D 2}$ (Asp121Asn)이며 다른 하나는 백색모의 Lnadrace와 Yorkshire 그리고 검은색 반점이 있는 Pietrain 이 속하는 $E^{P}$ (nt67insCC and Asp121Asn)이다. 붉은 모색을 나타내는 Duroc은 MC1R*4(Ala161Val and Ala240Thr)에 상응하는 recessive $e$ 대립유전자를 가지고 있었다.

최근에 발표된 Fang 등 (2009)의 논문에서는 31개 집단 을 대표하는 45마리의 유럽돼지와 19 품종을 대표하는 23 마리의 중국돼지의 MC1R 유전자형을 Kijas 등 (1998)이 기존에 정의한 $\mathrm{MC1R}$ 의 5 가지 유전자형보다 세분화하여 보고하였는데, $E^{+}$(Wild type)는 다시 5개의 형태 (0101 1015 )로 나누어지며 $E^{D l}$ (Dominant black)은 3 개의 형태 (0201 0203)로 분류되었다. $E^{D 2}$ (Dominant black)와 $e$ (Recessive red)는 한 가지 $(0301,0401)$ 로 고정되었으며, 흑 백반(black spotting)은 3개의 형태 (0501 0503)로 품종 별로 정확하게 재분류되었다.

국내에서 Genbank에 보고한 $\mathrm{MC1R}$ 염기서열가운데는 Kijas 등 (1998)이 분석한 $\mathrm{MC1R}$ 의 염기서열과 일부 차이 가 있다. 예를 들면, Landrace(AY365253)와 Yorkshire (AY365255)는 nt67insCC가 아닌 nt67insCCC가 상이하게 보고되었으며, Duroc(AY916524, AY916523)에서는 Ala161Val 과 $\mathrm{Ala} 240 \mathrm{Thr}$ 의 변이가 보고되어 있지 않았다. 그리고 한 국재래돼지 (AY365253)와 Hampshire (AY365251)서도 67번 코돈의 $\mathrm{CC}$ 결실 (deletion)이 $\mathrm{CCC}$ 결실로 보고 되었다.

따라서 본 연구에서는 돼지 $\mathrm{MC1R}$ 염기서열의 상이성을 재정립하여 $\mathrm{MC1R}$ 을 이용한 국내돼지품종식별 및 국내산 돈육제품의 경우 흑돈 브랜드제품 식별에 이용하고자 본 실험을 수행하였다. 특히 흑모색을 지배하는 돼지 $\mathrm{MC1R}$ 유전자형이 돈육의 육질특성에 영향을 미치는지를 조사하 여 우수한 육질의 흑돈 생산에 $\mathrm{MC1R}$ 유전자가 $\mathrm{DNA}$ 마 커로써 활용될 수 있는지 그 가치를 평가하였다.

\section{ㅍ. 재료 및 방법}

\section{1. 공시재료, DNA 추출 및 육질분석}

본 연구에 사용한 공시재료는 국립축산과학원의 한국재 래돼지 12두와 대한양돈협회 산하 종돈검정소에 종돈능력 평가에 이용된 Landrace (48두), Yorkshire (46두), Duroc (39 두) 및 Berkshire (48두)의 혈액으로부터 genomic DNA를 분리하여 이용하였다.

$\mathrm{MC} 1 \mathrm{R}$ 유전자 변이와 육질과의 연관성을 분석하기 위해 이용된 공시재료로는 충북 청원군에 위치한 샘터농장에서
한국재래돼지와 Yorkshire 품종의 양방향교배로 생산된 171 두의 F2 개체의 혈액에서 분리된 DNA가 이용되었다.

기초축군으로 활용된 한국재래돼지와 Yorkshire의 F2 집 단의 연관성분석을 위해 도체형질 및 육질형질에 대하여 조사하였다. 도체형질은 도축 직후 온도체중을 측정하였 으며 등지방두께는 10 번째와 11 번째 늑골에서 측정하였다. 체지방은 복강지방과 부분육으로부터 손질되어서 나온 지 방 무게를 측정하였다. 육질형질은 등심에서 $\mathrm{pH}$, 보수력, 가열감량, 전단력 및 일반성분 분석을 실시하였다. $\mathrm{pH}$ 는 도체 후 24시간에 측정하였으며 육즙손실량은 등심시료를 진공포장을 한 뒤에 24 시간후에 손실량을 측정하였다. 가 열감량은 $70^{\circ} \mathrm{C}$ 에서 40 분간 처리한 후 가열전후의 무게를 측정하였다. 전단력은 도축 24시간 후 12 번 늑골부위의 등심부위를 $3 \mathrm{~cm}$ 정도 두께의 스테이크 모양으로 절단하여 $70^{\circ} \mathrm{C}$ 에서 40 분간 가열하여 전단력측정기 (Warner-Bratzler shear force meter)로 측정하였다. 육색은 도축 후 24시간에 등심부위의 절개단면을 공기중에 30 분간 노출시킨 후에 CIE (Commision International de Leclairage) 값을 사용하여 Hunt $\mathrm{L}, \mathrm{a}, \mathrm{b}$ 값을 각각 측정하였다.

\section{2. 돼지 $\mathrm{MC} 1 \mathrm{R}$ 유전자 증폭 및 염기서열분석}

돼지 $\mathrm{MC1R}$ 유전자를 증폭하기 위하여 이용된 프라이머 는 Dun 등 (2007)이 보고한 4쌍의 oligonucleotides와 Cho 등 (2004)이 보고한 1쌍의 oligonucleotide를 사용하였다 (Table 1).

$\mathrm{DNA}$ 증폭을 위해 사용된 PCR 기계는 'PTC-200 thermocycler' (MJ Research, Watertown MA, USA)이며, hTaq polymerase (Solgent, Korea) 중합효소를 이용하였다. $\mathrm{PCR}$ 반응조건은 먼저 $95^{\circ} \mathrm{C}$ 에서 15 분 denaturation을 실시 하고, $95^{\circ} \mathrm{C}$ 20초, 각 프라이머에 최적화된 온도에서 (Table 1.) 40 초, $72^{\circ} \mathrm{C} 30$ 초씩 총 $40 \mathrm{cycles}$ 를 수행하였고 그 후 $72^{\circ} \mathrm{C}$ 에서 5 분간 최종반응을 실시한 후 종료하였다. $\mathrm{PCR}$ 증폭산물은 모두 $1.5 \%$ agarose gel의 $100 \mathrm{mV}$ 전압에서 30 분간의 전기영동을 통해 확인한 후 염기서열 분석 및 유 전자형 분석을 위한 제한효소처리에 이용하였다.

$\mathrm{MC1R}$ 유전자에서 증폭된 재래돼지의 $\mathrm{PCR}$ 증폭산물의 염기서열분석은 ‘ABI 3700 sequencer' (Applied Biosytem)에 의해 수행되었고, 'Sequencher 4.6' (Gene Codes, version 4.6 Anarbor, MI, USA) 프로그램을 이용하여 Genbank No. $\mathrm{AF} 326520$ 염기서열정보와 비교하여 돼지 MC1R유전자 변 이를 조사하였다.

3. 돼지 품종별 MC1R-Ala243Thr (G1554A)와 한국재 래돼지 x Yorkshire F2 집단의 MC1R-Leu102Pro (T1132C)의 유전자형 빈도 조사 
Table 1. Primers used to amplify regions of pig MC1R gene

\begin{tabular}{|c|c|c|c|}
\hline Primer & Primer sequence $\left(5^{\prime} \rightarrow 3^{\prime}\right)$ & Amplicon size & $\mathrm{Ta}\left({ }^{\circ} \mathrm{C}\right)$ \\
\hline \multirow{2}{*}{ Primer 1} & GCA GGG GTG TCT CTG TGT & \multirow{2}{*}{803 bp } & \multirow{2}{*}{58} \\
\hline & GAG TGC AGG GTT GCG GTT CT & & \\
\hline \multirow{2}{*}{ Primer 2} & GGC TGC TGG CTT CCC TCA & \multirow{2}{*}{$189 \mathrm{bp}$} & \multirow{2}{*}{58} \\
\hline & GGT TGC GGT TCT TGG CGA & & \\
\hline \multirow{2}{*}{ Primer 3} & ATG CCC GTG CTT GGC CCG GAG & \multirow{2}{*}{963 bp } & \multirow{2}{*}{69} \\
\hline & TCA CCA GGA GCA CTG CAG CAC & & \\
\hline \multirow{2}{*}{ Primer 4} & GAC CGC TAC GAG TCC ATC TT & \multirow{2}{*}{$136 \mathrm{bp}$} & \multirow{2}{*}{58} \\
\hline & TGT GGT GGT AGT AGG CGA TG & & \\
\hline \multirow{2}{*}{ Primer 5} & ACC CTC TTC ATC GCC TAC & \multirow{2}{*}{$256 \mathrm{bp}$} & \multirow{2}{*}{58} \\
\hline & AGA GGT GCA GGA AGA AGG & & \\
\hline
\end{tabular}

조사된 $\mathrm{MC1R}$ 유전자 변이의 빈도에 대한 품종별 분석 은 Landrace, Yorkshire, Duroc, Berkshire 4품종에 대해서 Dun 등 (2007)의 MC1R-5F/R 프라이머를 이용하여 증폭한 PCR 산물에서 Ala243Thr (G1554A) 변이를 인식하는 제한 효소 $B s t \mathrm{UI}$ 처리하여 수행하였다. $\mathrm{MC1R}$ 유전자형이 육 질에 미치는 영향을 분석하기 위한 실험은 재래돼지와 Yorkshire의 F2 기초축군을 이용하였으며, Cho 등 (2004)이 보고한 1 쌍의 oligonucleotide를 이용하여 유전자 증폭을 하고 $E^{D l}$ 형 구분의 기준이 되는 Leu102Pro (T1132C) 변이 를 인식하는 $M s p A 1 \mathrm{I}$ 제한효소를 처리하여 결정된 유전 자형을 이용하였다. Ala243Thr(G1554A)과 Leu102Pro(T1132C) 변이에 대한 유전자형 판정은 제한효소 최적반응 조건하 에서 4시간 이상 반응을 통해 절단된 단편들은 $2.5 \%$ agrose gel에서 $90 \mathrm{mV}$ 전압으로 40 분간의 전기영동을 통해 수행하였다 (Fig. 1).

\section{4. 통계 분석}

경제형질 측정치에 대한 MC1R-Leu102Pro (T1132C) 변이 의 유전자형 효과를 추정하기 위해 SAS 9.1 Package/PC를 이용하여 일반선형모형 (GLM) 분석을 하였으며, 유전자형 의 효과가 유의한 형질들에 대해 최소유의차 검정으로 평 균간 차이에 대한 유의성을 조사하였다. 통계분석에 이용 한 모형은 다음과 같다.

$$
\mathrm{Y}_{i j k}=\mu+\mathrm{S}_{i}+\mathrm{G}_{j}+\mathrm{e}_{i j k}
$$

위에서 $\mathrm{Y}_{i j k}=$ 형질의 측정치, $\mu=$ 전체 평균, $\mathrm{S}_{i}=$ 성별 효과 (1=거세돈, $2=$ 암퇘지), $\mathrm{G}_{j}=$ 유전자형 $(j=\mathrm{TT}, \mathrm{TC}$, $\mathrm{CC}), \mathrm{e}_{i j k}$ 는 임의오차를 나타내고 있다.
III. 결 과

\section{1. 돼지 $\mathrm{MC1R}$ 염기서열 분석 및 유전자형 결정}

재래돼지 12 두를 혼합한 4 개의 DNA 샘플에서 염기서열 분석을 통해 얻어진 $1451 \mathrm{bp}$ 의 재래돼지 염기서열은 Genbank에 등록되어있는 database (AF326520)와 비교한 후 Fang 등 (2009)이 보고한 14개의 SNPs와 유전자형을 분류 기준으로 삼아 분석하였다 (Table 2).

그 결과 한국재래돼지 $\mathrm{MC1R}$ 대립유전자형은 모두 $E^{D l}$ 형으로, $\mathrm{MC1R} E^{D 1}$ 을 결정짓는 코돈 Va195Met과 Leu102Pro 의 polymorphism을 가지고 있었으며 이 그룹에는 몸 전체가 흑모색인 중국재래종이 다수 포함되는 것으로 알려져 있다. 또한 중국야생종 $\left(E^{+}\right)$과 중국재래종에서 나타난 코돈 $17(\mathrm{G} \longrightarrow$ $\mathrm{A})$ 번의 A 대립유전자가 한국재래돼지에서도 동일하게 A 대 립유전자로 고정된 것으로 관찰되었다. 그러나 일부 변이에 서는 유럽종 우성흑모색 $\left(E^{D 2}\right)$ 의 대립유전자가 이형접합체의 형태로 나타났는데, $121(\mathrm{~T} \rightarrow \mathrm{C})$ 번과 $124(\mathrm{G} \rightarrow \mathrm{A})$ 번 그리고 $243(\mathrm{G} \rightarrow \mathrm{A})$ 번 코돈에서 재래돼지의 일부 샘플이 두 개의 서 로 다른 allele인 $E^{D 1}$ 와 $E^{D 2}$ 를 갖는 것으로 나타났다.

한국재래돼지가 속하는 $E^{D 1}$ 형을 Fang 등 (2009)이 결정 한 0201, 0202와 0203 세 가지 형태로 분류하였을 때, 한 국재래돼지는 0202 형을 구분하는 기준이 되는 코돈 122 번 $(\mathrm{G} \rightarrow \mathrm{A})$ 변이에서는 0202 형이 가진 $\mathrm{A}$ 대립유전자가 나타 나지 않았고, 0203을 구분하는 기준이 되는 코돈 124번 (C $\rightarrow \mathrm{T}$ ) 변이에서의 $\mathrm{T}$ 대립유전자가 나타나지 않아 0201의 $\mathrm{MC1R}$ allele로 고정된 것으로 판단된다.

\section{PCR-RFLP에 의한 돼지 품종별 MC1R-Ala243Thr $(\mathrm{G} 1554 \mathrm{~A})$ 유전자형 빈도 분석}


Table 2. DNA and amino acid sequence alignments of Korean native pig (KNP) MC1R/E allele

\begin{tabular}{|c|c|c|c|c|c|c|c|c|c|c|c|c|c|c|c|}
\hline & \multirow{2}{*}{$* \mathrm{MC} 1 \mathrm{R} / E$} & \multicolumn{14}{|c|}{ Codon } \\
\hline & & 4 & 17 & 21 & 22 & 95 & 102 & 117 & 121 & 122 & 124 & 164 & 166 & 243 & 301 \\
\hline \multirow{14}{*}{ Alleles } & $20101 / E^{+}$ & 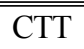 & 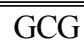 & 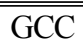 & 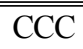 & 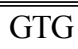 & בCTG & $\overline{\mathrm{CAAG}}$ & 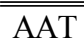 & 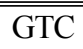 & 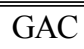 & 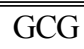 & 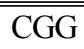 & 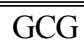 & $\overline{\text { TAC }}$ \\
\hline & $0102 / E^{+}$ & --- & --- & --- & --- & --- & --- & --- & $--\mathrm{C}$ & --- & --- & --- & --- & --- & --- \\
\hline & $0103 / E^{+}$ & --- & --- & --- & --- & --- & --- & --- & $-\mathrm{C}$ & -- & -- & --- & -- & -- & --- \\
\hline & $0104 / E^{+}$ & --- & $--A$ & --- & --- & --- & --- & --- & $--\mathrm{C}$ & --- & $--\mathrm{T}$ & --- & --- & $--A$ & $--\mathrm{T}$ \\
\hline & $0105 / E^{+}$ & --- & $--A$ & --- & --- & --- & --- & $--A$ & $--\mathrm{C}$ & --- & --- & --- & --- & $--A$ & $--\mathrm{T}$ \\
\hline & $0201 / E^{D I}$ & --- & $-\mathrm{A}$ & --- & --- & A-- & $-\mathrm{C}-$ & --- & $-\mathrm{C}$ & --- & -- & --- & --- & $--\mathrm{A}$ & --- \\
\hline & $0202 / E^{D I}$ & --- & $--A$ & --- & --- & A-- & $-\mathrm{C}-$ & --- & $--\mathrm{C}$ & A-- & --- & --- & --- & $--A$ & --- \\
\hline & $0203 / E^{D I}$ & --- & $--A$ & -- & --- & A-- & $-\mathrm{C}-$ & --- & $-\mathrm{C}$ & --- & $-\mathrm{T}$ & -- & --- & $--A$ & --- \\
\hline & KNP & --- & $--A$ & --- & --- & A-- & $-\mathrm{C}-$ & --- & $--Y$ & --- & R-- & --- & --- & $--R$ & --- \\
\hline & $0301 / E^{D 2}$ & --- & --- & --- & --- & --- & --- & --- & --- & --- & A-- & --- & --- & --- & --- \\
\hline & $0401 / e$ & --- & --- & --- & --- & --- & --- & -- & --- & --- & --- & $-\mathrm{T}-$ & --- & A-- & --- \\
\hline & $0501 / E^{P}$ & --- & --- & --- & $+\mathrm{CC}$ & --- & --- & --- & --- & --- & A-- & --- & --- & --- & --- \\
\hline & $0502 / E^{P}$ & --- & --- & A-- & $+\mathrm{CC}$ & --- & --- & --- & --- & --- & A-- & --- & --- & --- & --- \\
\hline & $0503 / E^{P}$ & --- & --- & --- & $+\mathrm{CC}$ & --- & --- & --- & --- & --- & A-- & --- & T-- & --- & --- \\
\hline \multirow{14}{*}{$\begin{array}{l}\text { Amino } \\
\text { acid }\end{array}$} & $0101 / E^{+}$ & Leu & Ala & Ala & Pro & Val & Leu & Gln & Asn & Val & Asp & Ala & Arg & Ala & Tyr \\
\hline & $0102 / E^{+}$ & $\cdot$ & $\cdot$ & $\cdot$ & $\cdot$ & $\cdot$ & $\cdot$ & $\cdot$ & $\cdot$ & $\cdot$ & $\cdot$ & $\cdot$ & $\cdot$ & $\cdot$ & $\cdot$ \\
\hline & $0103 / E^{+}$ & . & . & . & . & . & . & . & . & . & . & . & . & . & . \\
\hline & $0104 / E^{+}$ & . & . & . & . & . & . & . & . & . & . & . & . & . & . \\
\hline & $0105 / E^{+}$ & . & . & . & . & . & . & . & . & . & . & . & . & . & . \\
\hline & $0201 / E^{D I}$ & . & . & . & . & Met & Pro & . & . & . & . & . & . & . & . \\
\hline & $0202 / E^{D l}$ & . & . & . & . & Met & Pro & . & . & Ile & . & . & . & . & . \\
\hline & $0203 / E^{D I}$ & . & . & . & . & Met & Pro & . & . & $\cdot$ & . & . & . & . & . \\
\hline & KNP & . & . & . & . & Met & Pro & . & . & . & Asn & . & . & . & . \\
\hline & $0301 / E^{D 2}$ &. & $\cdot$ & . & . & $\cdot$ & $\cdot$ & . & . & . & Asn & $\cdot$ & . & $\cdot$ & $\cdot$ \\
\hline & $0401 / e$ & $\cdot$ &. &. & $\cdot$ & $\cdot$ & $\cdot 14$ & $\cdot$ & . &. & $\cdot$ & Val & . & Thr & $\cdot$ \\
\hline & $0501 / E^{P}$ & . & . & . & $\mathrm{FS}^{2}$ & . & $\cdot$ & . & . & . & Asn & $\cdot$ & . & $\cdot$ & . \\
\hline & $0502 / E^{P}$ & . & . & Thr & $\mathrm{FS}^{2}$ & . & . & . & . & . & Asn & . & . & . & . \\
\hline & $0503 / E^{P}$ & . & . & $\cdot$ & $\mathrm{FS}^{2}$ & . & . & . & . & . & Asn & . & . & . & . \\
\hline
\end{tabular}

* Nomenclature of porcine MC1R alleles in this table was obtained from Fang et al. (2009).

Dun 등 (2007)은 Landrace와 Yorkshire에서는 각각 668GG, $1318 \mathrm{CC}$ 그리고 $1554 \mathrm{GG}$ 의 동형접합체인 반면에 Duroc에 서는 $668 \mathrm{CC}, 1318 \mathrm{TT}$ 그리고 $1554 \mathrm{AA}$ 동형접합체인 Duroc 특이적인 변이를 보고하였다. 이 자료를 근거로 하여 $\mathrm{MC1R}-5 \mathrm{~F} / \mathrm{R}$ 프라이머를 제작하고 대한양돈협회 산하 종돈 검정소에 출하된 순종집단(Landrace, Yorkshire, Berkshire, Duroc) 각각 $48,46,48,39$ 두에 대하여 $\mathrm{Ala}$ 에서 $\mathrm{Thr}$ 으로의 아미노산 치환을 일으키는G1554A 변이를 PCR- RFLP 분 석을 수행하였다 (Fig. 1).

$\mathrm{PCR}$ 증폭반응결과 $256 \mathrm{bp}$ 의 산물을 얻었고, 제한효소 $B s t \mathrm{U}$ I 을 이용하여 절단하였는데 Kijas 등 (1998)의 보고에 따르면 Duroc의 $\mathrm{MC1R}$ Extension 좌위의 유전자형은 $e$, Landrace와 Yorkshire $E^{p}$ 그리고 Berkshire는 $E^{D 2}$ 으로, G1554A 변이는 Duroc 개체만을 식별 할 수 있는 인지부 위로써 Duroc에서 AA형으로 고정되어 있어야 한다. 실험
결과 본 실험에 사용된 Duroc에서 $\mathrm{GG}$ 형은 출현하지 않 았으나 $\mathrm{GA}$ 이형접합체가 충 39 마리 중 8 마리가 출현함 으로써 이형접합체의 비율은 0.2 로 나타났다. 그리고 Landrace와 Yorkshire의 대립유전자형은 $\mathrm{GG}$ 형으로 고정 되어 있어야 하지만 Landrace는 48마리 중 5마리, Yorkshire는 46마리 중 5마리가 이형접합체로 출현하였다. 각각의 빈도는 $0.1,0.1$ 로 나타났다. 하지만 Berkshire는 기 보고된 결과와 동일하게 모두 $\mathrm{GG}$ 대립유전자형을 가지고 있었다 (Table 3)

3. MC1R-Leu102Pro (T1132C) 유전자형과 육질형질 표현형간의 연관성 분석

흑모색과 관련이 있다고 보고된 MC1R-Leu102Pro (T1132C) 변이가 육질 및 도체형질에 미치는 영향을 알아 


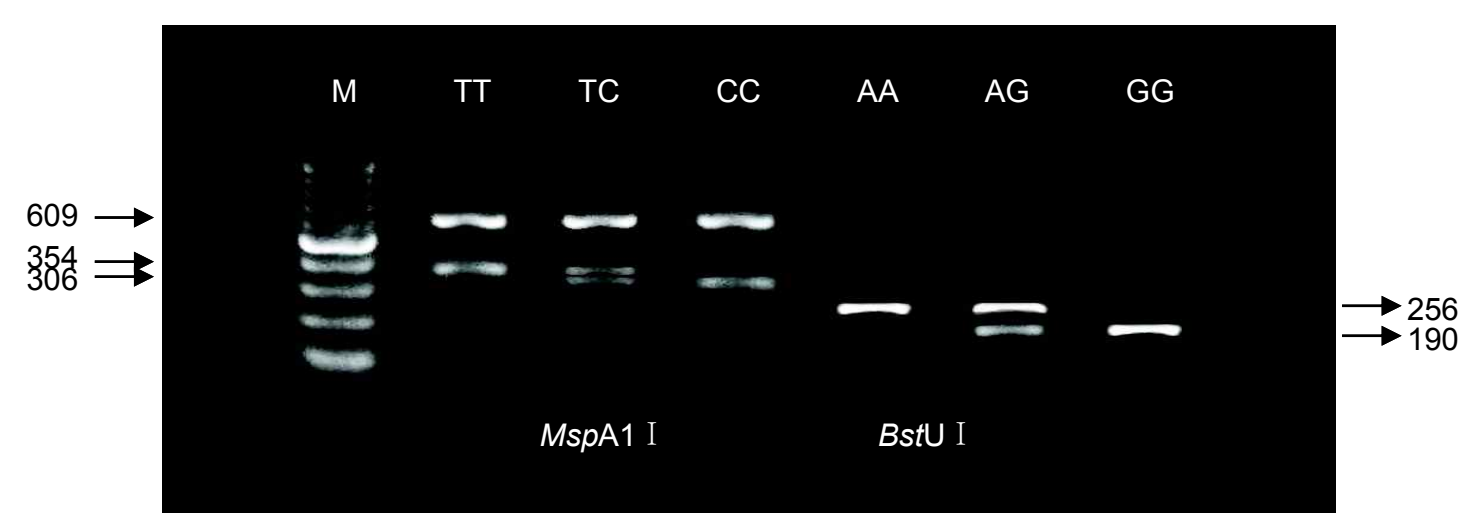

Fig. 1. Genotyping of Porcine MC1R polymorphisms.

PCR products were digested by MspA1I and BstUI M is 100bp ladder.

Table 3. G1554A SNP genotype frequency for MC1R gene in four different pig breeds

\begin{tabular}{cccccc}
\hline \multirow{2}{*}{ Locus } & \multirow{2}{*}{ Genotype } & \multicolumn{4}{c}{ Breed } \\
\cline { 3 - 6 } & & Duroc (n=39) & Landrace $(\mathrm{n}=48)$ & Yorkshire (n=46) & Berkshire (n=48) \\
\hline \hline \multirow{2}{*}{ Ala243Thr } & GG & & $0.9(43)$ & $0.9(41)$ & $1(48)$ \\
G1554A & GA & $0.2(8)$ & $0.1(5)$ & $0.1(5)$ & \\
& AA & $0.8(31)$ & & & \\
\hline
\end{tabular}

보기 위하여 한국재래돼지와 Yorkshire를 교잡하여 조성한 며 두 가지 동형접합자와 이들의 이형접합자가 모두 출현 F2 집단에서 MspA1I PCR-RFLP 분석방법을 이용하여 유 하였고 각각의 빈도는 TT $0.68, \mathrm{TC} 0.29, \mathrm{CC} 0.02$ 로 확인 전자형을 결정하여 표현형간의 연관성 분석을 실시하였다 되었다. 주요 "도체형질인 생시체중, 수분, 단백질, 지방, (Table 4). 총 171 개의 DNA 샘플을 대상으로 분석되었으 보수력, 콜레스테롤, 근내지방도, 조직감, 연도, 다즙성, 명

Table 4. Least square means of pork quality traits with MC1R Leu102Pro polymorphism in F2 by mating between two reciprocal families of Korean native pig and Yorkshire

\begin{tabular}{crrrc}
\hline \multirow{2}{*}{ Trait } & \multicolumn{4}{c}{ MC1R genotype } \\
\cline { 2 - 5 } & \multicolumn{1}{c}{ TT } & \multicolumn{1}{c}{ TC } & CC & P value \\
\hline \hline live weight (kg) & $92.87 \pm 1.07$ & $93.51 \pm 1.72$ & $86.67 \pm 6.88$ & 0.62 \\
Moisture (\%) & $74.10 \pm 0.15$ & $73.57 \pm 0.24$ & $73.96 \pm 0.85$ & 0.17 \\
crude protein (\%) & $21.93 \pm 0.16$ & $22.13 \pm 0.25$ & $22.10 \pm 0.89$ & 0.79 \\
crude fat (\%) & $2.49 \pm 0.13$ & $2.68 \pm 0.20$ & $2.80 \pm 0.74$ & 0.70 \\
Water holding capacity (\%) & $58.73 \pm 0.56$ & $58.57 \pm 0.88$ & $56.55 \pm 3.15$ & 0.78 \\
Cholesterol (mg/100g) & $138.60 \pm 6.88$ & $116.08 \pm 11.02$ & $88.87 \pm 39.38$ & 0.13 \\
Marbling* & $2.39 \pm 0.09$ & $2.62 \pm 0.15$ & $2.33 \pm 0.53$ & 0.43 \\
Texture* & $2.85 \pm 0.04$ & $2.96 \pm 0.06$ & $3.04 \pm 0.22$ & 0.26 \\
Tenderness* & $3.01 \pm 0.07$ & $3.10 \pm 0.11$ & $3.63 \pm 0.40$ & 0.26 \\
Juiciness* & $3.01 \pm 0.04$ & $3.00 \pm 0.06$ & $3.01 \pm 0.21$ & 0.97 \\
Lightness (Hunt $\mathrm{a}^{*}$ ) & $52.50 \pm 0.45$ & $52.75 \pm 0.72$ & $56.20 \pm 2.58$ & 0.36 \\
Redness (Hunt $\mathrm{b}^{*}$ ) & $5.48 \pm 0.17$ & $5.34 \pm 0.28$ & $7.37 \pm 1.00$ & 0.14 \\
\hline
\end{tabular}

* Marbring, 1: extremely low in intramuscular fat, 5: very abundant in intramuscular fat.

* Texture, Tenderness and Juiciness, 1: extremely bad, 5: very good. 
도, 적색도에 대하여 $\mathrm{MC1R}$ 유전자 Leu102Pro 비교를 수 행한 결과 모든 형질에서 유의적인 차이를 나타내지 않았 다 (Table 4).

\section{IV. 고 찰}

본 연구에서는 한국재래돼지 $\mathrm{MC1R}$ 유전자 염기서열을 증폭하여 Fang (2009) 등의 분류 기준에 따라 정의하고, 대 한양돈협회 산하 검정소에 입식되어 사육되고 있는 종돈 의 품종 별 유전자형을 분석하였는데, 국내 F1 교잡 모계 라인에서의 비유암퇘지 (Duroc 교잡) 혼입이 있을 수 있는 지를 분석하였다. 그리고 소비자에게 육질이 우수하다고 알려져 있는 재래돼지의 유전자형을 분석하여 흑모색을 야기하는 변이가 육질과 실제 어떤 상관관계가 있는지 한 국재래돼지와 Yorkshire F2 교잡집단에서 분석함으로써 밝 히고자 하였다.

돼지 MC1R의 유전자형은 Fang 등 (2009)이 새롭게 분류 하였는데 총 14 개의 polymorphism을 가지고 기존에 보고 되었던 5 종류의 유전자형을 보다 세분화하였다. 이 분류 기준에 따라 재래돼지의 유전자형을 확인하기 위해 염기 서열 분석을 실시하여 Fang 등 (2009)이 보고한 다른 품종 과 비교 하였다. 선행연구에 의하면 $\mathrm{Kim}$ 등 (2001)은 재래 돼지 $\mathrm{MC1R}$ 유전자형을 $M C 1 R^{*} 1$ 과 $M C 1 R^{*} 2$ 로 보고하였고 Cho 등 (2002)은 $M C 1 R^{*} 2$ 와 $M C 1 R^{*} 3$ 으로 보고하였다. 그리 고 $\mathrm{Cho}$ 등(2004)도 $M C 1 R^{*} 3$ 으로 보고하였다. 본 실험의 결 과에 따르면 $M C 1 R^{*} 1$ 과 연관되어 있으며 유럽과 중국의 Wild boar 품종들에게 고정된 $E^{+}$의 대립유전자형은 공시 된 재래돼지에서는 나타나지 않았다. $M C 1 R^{*} 2$ (Dominant black)은 중국의 많은 재래종에서 나타난 유전자형이며 $E^{D l}$ 형과 연관되어 있는데 $E^{D l}$ 형의 검은색 모색 발현을 야기시키는 변이로 알려진 두 개의 missense mutation (V95M, L102P)이 모든 재래돼지의 샘플에서 발견되었다 (Kerong 등, 2004). 그리고 Wild boar 와 중국재래종에서만 나타나는 3 개의 synonymous substitution도 발견되었다. $E^{D I}$ 의 유전자형은 3가지(0201 0203)로 다시 나뉘게 되는데 재래돼지가 이들 중 어디에 속하는지 비교해 보면 0202와 0203 형을 각각 구분하는 기준이 되는 122 번과 124 번 코돈 의 변이가 발견되지 않았고 이러한 결과로 봤을 때 한국 재래돼지의 유전자형은 $E^{D l}$ 형 중에서도 0201에 속하는 것으로 추정할 수 있다. 그런데 일부 재래돼지에서는 $M C 1 R^{*} 3$ 에 속하는 $E^{D 2}$ 유전자형이 발견되었다. 121 번과 124 번 그리고 243 번 코돈의 변이의 여부로 $M C 1 R^{*} 2$ 와 $M C 1 R^{*} 3$ 을 구분할 수 있는데 일부 재래돼지의 샘플에서 이형접합체가 출현하였다. $M C 1 R^{*} 3$ 은 Hampshire와 Berkshire 같은 유럽의 흑백혼합모색품종이 속하는 $E^{D 2}$ 와 Landrace, Yorkshire와 같은 백색모색을 가진 품종이 속하는 $E^{P}$ 형이
있다. 이 중 백색품종에서만 확연하게 나타나는 22 번 코 돈의 $\mathrm{CC}$ insertion이 한국재래돼지에서는 없는 것으로 보 아 발견된 이형접합체는 $E^{P}$ 보다는 $E^{D 2}$ 에서 기인한 것으 로 추정되며 개량과정 중 특히 Berkshire 품종의 영향을 받는 것으로 사료된다. 과거 많은 유럽 품종이 국내로 들 어오면서 재래돼지의 개량에 교잡이 되었다가 재래돼지를 복원하는 과정에서 모색이나 체형 등의 외모심사에 의해 수집되어 보존되어온 실정을 고려하면 이 같은 결과를 예 측을 가능하며, 이는 또한 재래돼지 유전자형을 $M C 1 R * 3$ 으로 보고한 Lee 등 (2001)과 Cho 등 $(2002,2004)$ 의 결과 와 일치한다. Cho 등 (2004)은 Hampshire와 재래돼지에서 22 번 코돈의 $\mathrm{CC}$ 결실을 $\mathrm{CCC}$ 결실로 보고하였고 Genbank 에는 이를 포함한 재래돼지 염기서열이 등록되어 있다 (AY365252), 그런데 본 실험에 이용된 재래돼지의 염기서 열 분석 결과에서는 CC 결실로 나타났으며 Kijas 등(1998) 의 결과와 일치하였다.

한편, 우리나라에서 비육돈 생산에 이용되고 있는 4개 의 주요 품종에 대하여 MC1R-Ala243Thr $(\mathrm{G} 1554 \mathrm{~A})$ 유전자 형을 결정하여 종돈의 유전적 순수성을 검정하였다. MC1R-Ala243Thr (G1554A) polymorphism은 Duroc 품종을 구별해 낼 수 있는 특이적인 $\mathrm{SNP}$ 로 Duroc은 AA로, Duroc 을 제외한 나머지 품종에서는 $\mathrm{GG}$ 형으로 고정되어 있어야 하지만 Berkshire 품종을 제외한 Landrace, Duroc, Yorkshire 품종에서 이형접합체가 출현하였다. 우리나라의 양돈업에 서 이용되는 종돈은 Landrace, Yorkshire, Duroc 품종으로 현재 국내의 비육용 돼지는 Landrace (L)와 Yorkshire $(\mathrm{Y})$ 의 교잡암퇘지에 Duroc (D) 수퇘지를 교배하여 생산하는 삼원 교잡종 $(\mathrm{YLD})$ 이 널리 이용된다. 그런데 이러한 과정 중 Landrace와 Yorkshire를 이용한 F1 모계라인에서, 비육돈 암컷이 모계로 이용되는 경우가 있으며 이를 외형만으로 정확하게 구분하기 어려운 경우도 있다. 이러한 경우 본 실험에서의 결과처럼 $\mathrm{GA}$ 이형접합체나 $\mathrm{AA}$ 형 유전자형이 나타나게 된다. 또한 Duroc의 경우 교잡돈의 순종둔갑 문 제가 발생하기도 한다. 이렇게 외형만을 기준으로 품종을 구분할 때 비육돈이 종돈으로 선발되어 쓰이는 경우 모계 능력의 저하를 초래하게 되거나 고급육제품에 이용되는 좋은 육질의 비육돈을 생산하는데 문제를 초래하게 되면 서 농장생산력의 저하를 가져올 수도 있다. 유전자형 빈 도만을 가지고 교잡의 정도를 정확하게 판단하는 것은 무 리가 있으나 우수한 비육돈 생산라인을 구축하고 유지하 기 위해서는 정확한 혈통을 바탕으로 순수한 혈통을 유지 하고 관리 되어야 하며, 따라서 종돈 선발 시 표현형에 의존하여 발생할 수 있는 문제를 보완할 수 있는 품종 특 이적인 $\mathrm{DNA}$ 마커 연구의 필요성이 대두된다.

돈육의 품질에 영향을 미치는 중요한 특성들에는 보수 성, 조직감, 육색 등이 있으며 (van der Wal 등, 1997) 돈육 
의 다즙성과 연도 그리고 풍미는 근내지방과 연관되어 있 다고 보고되었다(Fortin 등, 2005). Table 4는 검은색 모색 발현과 관련되어 있는 MC1R Leu102Pro(T1132C) 변이를 분석함으로써 $\mathrm{MC1R}$ 유전자형과 도체형질간의 연관성을 나타낸 것으로 $\mathrm{MC1R}$ 유전자형은 모든 도체형질에 대하여 유의적인 상관관계를 나타내지 않았다. 이로써 $\mathrm{MC1R}$ 의 유전자형은 육질형질과 연관되지 않은 것을 확인할 수 있 으며 나아가 검은색 모색은 육질에 영향을 미치지 않는다 는 사실을 보여주고 있다.

재래돼지는 전신흑모색으로 등지방 두께가 두껍고 성장 률 및 사료효율이 낮으나 조단백질과 조지방 함량이 높고 단단한 지방조직과 붉은 육색과 백색의 지방을 가지며 풍 부한 육즙으로 육질이 우수하다고 알려져 있다. 그러나 이는 모색과는 연관되지 않은 재래돼지 품종의 자체의 특 성으로 다른 육질 연관 유전자가 관여하고 있을 것으로 사료되며 이에 대한 연구가 필요할 것으로 보인다.

최근에는 식육 및 육제품에 대한 소비자의 욕구가 다양 해지고 브랜드돈육에 대한 관심이 높아지면서 육질이 우 수하다고 알려진 한국재래돼지가 새롭게 주목 받고 있다. $\mathrm{MC1R}$ 유전자 내 변이는 소비자들의 고품질, 고급육 선호 추세에 맞추어 우리나라 고유의 유전자원인 재래돼지를 순수한 품종으로 복원시키고 관리하는 데에 활용가치가 있으며, 아울러 국내에서 사육되는 주요 품종들을 식별하 는데 이용할 수 있는 가능성을 제시하고 있다.

$$
\text { V. 요 약 }
$$

본 연구는 한국재래돼지의 $\mathrm{MC1R}$ 유전자형을 결정하고 $\mathrm{MC} 1 \mathrm{R}$ 유전자의 변이와 육질과의 연관성을 규명하기 위하 여 실시하였다. 재래돼지의 $\mathrm{MC1R}$ 유전자형을 분석한 결 과 중국재래돼지품종이 속하는 $E^{D l}$ 내에서도 0201형에 속 하는 것으로 나타났으며 몇몇의 재래돼지에서는 $E^{P}$ 유전 자형이 출현하였는데 이는 Berkshire 품종의 혼입으로 인 한 것으로 사료된다. 흑색의 모색과 관련되어 있다고 보 고된 Leu102Pro(T1132C) 변이를 재래돼지와 Yorkshire의 양방향 교배로 생산된 F2 집단의 171 두를 대상으로 분석 하고 육질형질과의 연관성을 분석하였다. 모든 육질형질 에 대하여 유의적인 효과를 나타내지 않았으며 이로써 돼 지의 흑색모색과 육질과는 연관성이 없으며 다른 육질관 련 유전자에 의해 영향을 받는다는 근거를 제공하였다. 또한 Duroc 품종에서 $\mathrm{AA}$ 으로 고정되어 있어 다른 품종과 의 구분 기준이 되는 $\mathrm{Ala} 243 \mathrm{Thr}(\mathrm{G} 1554 \mathrm{~A})$ 변이를 이용하 여 종돈검정소에서 출하된 Landrace, Yorkshire, Duroc, Berkshire 순종집단에 대한 유전자형 빈도를 조사하였으며 Berkshire를 제외한 나머지 품종에서 이형접합체가 일부 출현하였다.

\section{VI. 사 사}

이 논문은 2007년도 충북대학교 학술연구지원사업의 연 구비 지원에 의하여 수행되었고, 하유경과 최정석 학생은 2 단계 $\mathrm{BK} 21$ 사업의 장학금 수혜를 받았습니다. 농촌진층청 바이오그린 21 "DNA 마커 도움선발을 이용한 한국재래돼 지 개량과 상업적 비육흑돼지 계통조성”의 시료제공에 감 사드리며 이를 위해 연구결과 일부가 제공되었습니다. 본 논문의 완성도와 질적 수준 향상에 도움을 주신 익명의 심사위원님들께 감사드립니다.

\section{VII. 인 용 문 헌}

1. Cho, I. C., Lee, J. K., Jung, J. K., Yang, B. S., Kang, S. Y. and Kim, B. W. 2002. Studies on the MC1R Gene Frequencies in Landrace, Large White, Duroc and Jeju Native Black Pigs. J. Anim. Sci. \& Technol. (Kor). 44, 207-212.

2. Cho, I. C., Jung, Y. H., Jung, J. K., Seong, P. N., Oh, W. Y., Ko, M. S., Kim, B. W., Lee, J. G. and Jeon, J. T. 2004. Detection of Novel Genetic Variations of the $M C 1 R^{*} 3$ Allele in Pig (Sus scrofa). J. Anim. Sci. \& Technol. (Kor). 46, 1-6.

3. Dun, G., Li, X., Cao, H., Zhou, R. and Li, L. 2007. Variation of Melanocortin Receptor $1(M C 1 R)$ Gene in Three pig Breeds. J. Genet Genomics. 34, 777-782.

4. Fang, M., Larson, G., Ribeeiro, H. S., Li, N. and Andersson, L. 2009. Contrasting mode of Evolution at a Coat Color Locus in Wild and Domestic Pigs. PLoS Genetics. 5, e1000341.

5. Fortin, A., Robertson, W. M. and Tong, A. K. W. 2005. The eating quality of Canadian pork and its relationship with intramuscular fat. Meat Sci. 69, 297-305.

6. Kerong, S., Aiguo, W., Ning, L. and Xuemei, D. 2004. Single nucleotide polymorphism analysis in melanocortin receptor (MC1R) of Chinese native pig. Sci China C Life Sci. 47, 287-292.

7. Kijas, J. H., Wales, R., Tornsten, A., Chardon, P., Moller, M., and Andersson, L. 1998. Melanocortin Receptor 1 (MC1R) Mutations and Coat color in Pigs. Genetics. 150, 1177-1185.

8. Kim, T. H., Yoon, D. H., Nho, W. G., Yeon, S. H., Kim, N. S., Lee, H. J., Cheong, I. C. and Han, J. Y. 2001. Genetic Variation of Melanocortin Receptor $1(M C 1 R)$ in Korean Native Pig. J. Anim. Sci. \& Technol. (Kor). 43, 293-302.

9. Klungland, H., Vage. D. I., Gomez, R. L., Adalsteinsson, S. and Lien, S. 1995. The role of Melanocyte-stimulating hormone (MSH) receptor in bovine coat color determination. 
Mamm Genome. 6, 636-639.

10. Lee. S. S., Yang, B. S., Jung, J. K., Ko, S. B., Oh, S. J., Yang, Y. H., Kim, K. I., Li, Z. D. and Feng, S. T. 2001. Comparison of the Genotype of melanocortin Receptor 1 $(M C 1 R)$ Gene in Korean-native and Chinese-native Pigs. J. Anim. Sci. \& Technol. (Kor). 43, 1-8.

11. Mariani, P., Johansson Moller, M., Hoyheim, B., Marklund, L. and Davies, W. 1996. The extention coat color locus and the loci for Blood Group $\mathrm{O}$ and Tyrosine Aminotransferase are on pig chromosome 6. J. Hered. 87, 272-276.

12. Marklund. L., Johansson, M., Sandberg, K. and Andersson, L. 1996. A missense mutation in the gene for melanocytestimulating hormone receptor $(M C 1 R)$ is associated with the chestnut coat color in horses. Mamm. Genome. 7, 895-899.

13. Newton, J. M., Wilkie, A. L., He, L., Jordan, S. A. and
Metallinos, D. L. 2000. Melanocortin 1 receptor variation in the domestic dog. Mamm. Genome. 11, 24-30.

14. Takeuchi, S. H., Suzuki, H., Yabuuchi, M. and Takahashi, S. 1996. A possible involvement of melanocortin 1-receptor in regulating feather color pigmentation in the chiken. Biochm. Biophys. Acta. 1308, 164-168.

15. Valverde, P., Healy, E., Jackson, I., Rees, J. L. and Thody, A. J. 1995. Variants of the melanocyte-stimulating hormone receptor gene are associated with red hair and fair skin in humans. Nature Genet. 11, 328-330.

16. van der Wal, P. G., Engelb, B. and Hulsegge, B. 1997. Causes for variation in pork quality. Meat Sci. 46, 319-327. (접수일자 : 2009. 5. 8. / 수정일자 : 2009. 6. 1. /

채택일자 : 2009. 6. 9.) 